\title{
КОНЦЕПЦИЯ ПЕРЕРАБОТКИ ДРЕВЕСНЫХ МАТЕРИАЛОВ
}

\author{
П.М. Мазуркин
}

Обоснованы нормативы производства в России кругляка, пиломатериалов, древесных плит, бумаги и картона в России до 2040 г. на основе учета передового мирового опыта с 1961 по 2004 г. Представлены методы эконометрического анализа динамики показателей лесопользования, проведен анализ особенностей лесной политики ведущей в лесном деле стран: Японии, Финляндии, Швеции, Германии и других.

Ключевые слова: древесное сырье, переработка, технологические уровни, возможности России

Production standards in Russia of a round timber, timber, wood plates, paper and a cardboard in Russia till 2040 on the basis of the accounting of the best world practices from 1961 to 2004 are proved. Methods of the econometric analysis of dynamics of indicators of forest exploitation are presented, the analysis of features of forest policy of the leader in forest business of the countries is carried out: Japan, Finland, Sweden, Germany and others.

Keywords: wood raw materials, processing, technological levels, possibilities of Russia

Введение. Выявление передовых в лесном деле стран из 182, по динамике леса и древесной продукции за период с 1961 по 2004 гг., было проведено в книге [1]. Эти результаты в последнем разделе книги завершаются динамикой значений нормативов лесопользования. Их можно достичь к 2050 г. Они не учитывались в бывшем СССР, а национальный лес и в России считается безграничным и бездонным природным богатством. Понимание уровней переработки и их объемов пока также нет.

В нашей стране не было и пока отсутствует разумная стратегия лесопользования [2-22]. Это было показано статистическим моделями динамики площади леса, объемов заготовки (а также процессов импорта и экспорта) кругляка, пиломатериалов, древесных плит и бумажной продукции. В целом, за прошедшие 50 лет, лесное дело в России характеризуется хаотическим волновым изменением, имеющим значительную амплитуду и увеличивающуюся частоту колебательного разрушения лесного дела.

Путем устранения причин сознательного искажения статистической отчетности по отраслям лесного дела необходимо заново возрождать тот единственный научный подход, который был заложен трудами лесовода Г.Ф.Морозова и устроителя леса М.М.Орлова. Отсутствие прошлых данных о лесах и лесном деле на уровне субъектов Российской Федерации тормозит развитие лесной науки и лесного дела. Информационно беспомощными являются лесничества, и даже Рослесхоз в целом. В такой ситуации единственно объективным научным подходом становится сравнительная статистическая динамика.

Благодаря систематизированной за 19612004 гг. информации по всем странам мира о лесах и лесном деле, нам удалось выявить закономерности изменения площади национальных лесов 182 стран. При этом 15 бывших советских республик не принимались в расчет, так как Россия оказалась основным преемником, как советского леса, так и лесного дела СССР в целом. Поэтому за 44 года рассматривалось страна под условным названием СССР-Россия. Из учтенных $182+15=197$ стран лучшими по росту площади леса оказались 31 страна, в число которых входил и СССР (Россия пока не в счет, так как нужны данные по лесу за 1995-2014 гг.).

Затем были отобраны по критерию превышения темпов роста площади леса над темпами производства кругляка 10 стран, в их число из-за резкого снижения объемов заготовки круглых лесоматериалов входит и СССР. Системный кризис благотворно сказался на снижении объема заготовляемого кругляка, а эта мировая тенденция осознанного спада уже была в передовых в лесном деле странах почти с 1975 года.

По показателю удельной заготовки кругляка с одного гектара национального леса лучшими оказались всего семь стран: Япония, Италия, Румыния, Греция, Финляндия, Норвегия и СССР.

Закономерности статистической динамики показали, что в СССР не было никакой осознаваемой лесной политики, и объемы лесного дела изменялись с сильным волновым возмущением, приведшим к краху. Причем лесная отрасль пришла бы своему краху и без системного кризиса всей страны.

Современный уровень нагрузки на лесные массивы России по удельной заготовке кругляка является наилучшим, и этот показатель надо удерживать на достигнутом уровне. По валовому 
показателю заготовки кругляка ни в коем случае не нужно стремиться к высоким результатам, достигнутым в лучшие годы существования СССР (350 млн. м $\left.{ }^{3}\right)$ и уж тем более не догонять США (около 500 млн. м ${ }^{3}$ ), где лес страдает из-за сильного переруба.

Нормативы древесной продукции. Для развертывания реформы лесного дела, в особенности правильного внедрения системы лесной аренды, в России чрезвычайно важно знать на далекую перспективу нормативы лесопользования с одного гектара лесного фонда, в особенности по заготовке кругляка и глубокой переработке древесных ресурсов.

По данным ФАО ООН с 1961 г. можно дать прогнозы о передовых в лесном деле странах до 2040 г. При этом сравнительные нормативы будут полезны для применения в стратегическом управлении мировым лесом как единственно значимым жизненным богатством для будущего человечества.

Сравнение стран по извлечению кругляка из леса. Сопоставление графиков на рисунке 1 показывает, что по динамике заготовки кругляка с единицы площади национального леса лидирует Япония. Именно её опыт проведения рубок переформирования и обновления, а также обустройства истощенных и расстроенных лесных участков станет основой для многих субъектов Российской Федерации.

Наша страна имела наименьшие значения показателя удельной заготовки кругляка с 1 га леса. Но это средние значения преогромной территории. Гораздо более пестрой будет картина после анализа производства кругляка в отдельных субъектах Федерации. Поэтому значения показателя удельного извлечения кругляка из лесного фонда для 88 субъектов Российской Федерации будут изменяться в значительных пределах.

В 1961 г. Япония заготовляла кругляка с 1 га своего леса в семь раз больше, чем СССР. Однако в нашей стране громадность территории и возможность выбора лучших деревьев (рубки ухода при промежуточном лесопользовании, лучшие делянки для сплошных рубок с оставлением недорубов в лиственном лесу и др.) превратили лесное хозяйство в простой придаток лесозаготовительной отрасли. Последняя вообще отделилась от лесного хозяйства не только в виде отдельного министерства, но и в лесной науке и образовании заготовка, вывозка и первичная обработка на лесопромышленных складах разделились по отдельным направлениям. В итоге це- лостность лесной науки была потеряна и сложилась в СССР парадоксальная ситуация: специалисты узких лесоинженерных специальностей и специализаций оказались почти полностью оторванными от теории лесоведения и лесоводства.

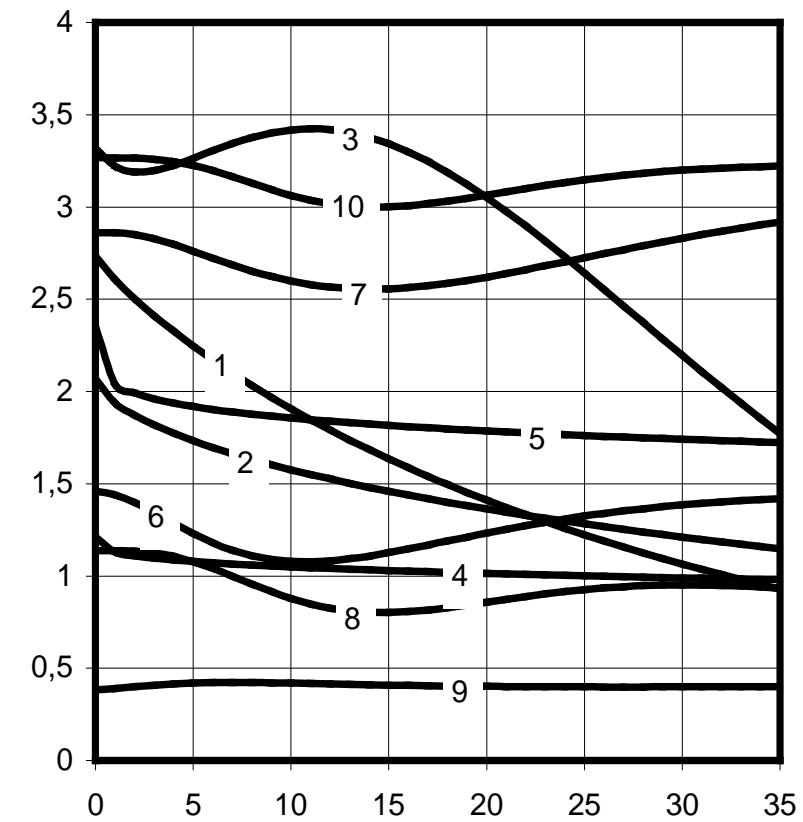

Рис. 1. Сравнение графиков трендов динамики удельной заготовки кругляка с одного гектара леса, $\mathrm{m}^{3} / \mathrm{ra}$ :

1 - Япония; 2 - Италия; 3 - Румыния; 4 - Греция; 5 - Финляндия; 6 - Норвегия; 7 - Франция; 8 - Испания; 9 - СССР; 10 - Тунис

Таким образом, в Японии активная заготовка кругляка заставила сконцентрироваться лесное дело в одно целостное направление. В CССР, где в семь раз меньшее по сравнению с Японией производилось кругляка с гектара леса, население хищнически вырубало лучшие деревья, а лесное ведомство и лесная наука выбрали сторону упрощенчества в способах и средствах заготовки кругляка. В отличие от людей хищники отбирают слабые и больные жертвы, а лучшие особи не трогают, «заботясь» о своем будущем. Люди же безжалостно уничтожают лучшее, ничуть не думая о том, что ждет их впереди.

К 1994 г. Япония, снижая показатель удельного извлечения кругляка из леса, всё еще не достигла уровня России - примерно 0,4 м³/га заготовленного кругляка на гектаре. В СССР, а затем и в России, этот показатель не изменился, и поэтому говорить об интенсификации лесного хозяйства не приходится.

Низкое значение удельного извлечения кругляка из национального леса для России, как и низкий уровень энергетического и трудового обеспечения процессов заготовки кругляка, объясняется несколькими причинами: 
a) слишком суровый климат в лесных зонах на территории России (в теплых краях деревья почти полностью вырублены) не дает значительного прироста деревьев по древесине, поэтому тем осторожнее надо относиться потомкам к оставшимся отечественным лесам, получая прибыль не от рубки деревьев, а от улучшения древостоев и посадки новых насаждений, требуя от других стран за хвойные посадки плату (по Киотскому протоколу);

б) низкий уровень извлечения кругляка с единицы площади леса (если повышать активность рубки, то придется со временем все равно вернуться к низким значениям удельного извлечения кругляка из лесных массивов). Необходимо обращать наибольшее внимание на производство древесных плит и бумаги, что позволит значительно вовлечь в хозяйственный оборот низкокачественную древесины и отходы лесного хозяйства и деревообработки;

в) низкий технический уровень всех процессов лесопользования в сфере заготовки и потребления древесного сырья (даже тот факт, что в СССР было приято создавать колоссальные запасы древесины на верхних, промежуточных и нижних лесопромышленных складах, указывает на чрезвычайно низкий уровень технологического освоения эксплуатируемых лесов).

В стратегическом отношении на 30 и более лет вперед нынешний низкий уровень удельного извлечения кругляка из российского леса является благом для природы. А может быть, в реальности удельная заготовка кругляка фактически в два раза больше из-за криминальных способов лесозаготовки. Тогда Россия уступает Японии только в 1,5 раза, если исходить из принципа неистощения своего леса.

Сравнение стран по распиловке извлечения из леса кругляка. Из рисунка 2 видно, что резко отличается от всех стран Япония, которая в значительных объемах импортирует кругляк чужого производства.

По данному показателю неплохо выглядел СССР. Но в стране никогда не учитывались процессы обращения кругляка в целом (импорт, производство и экспорт) и других групп древесной продукции. СССР стремился быть самодостаточной страной в основном по производству и гипертрофированному экспорту кругляка.

Таким образом, отношение объемов производства пиломатериалов к объему кругляка является методически неверным (Госплан СССР использовал в сравнениях по годам именно это отношение).

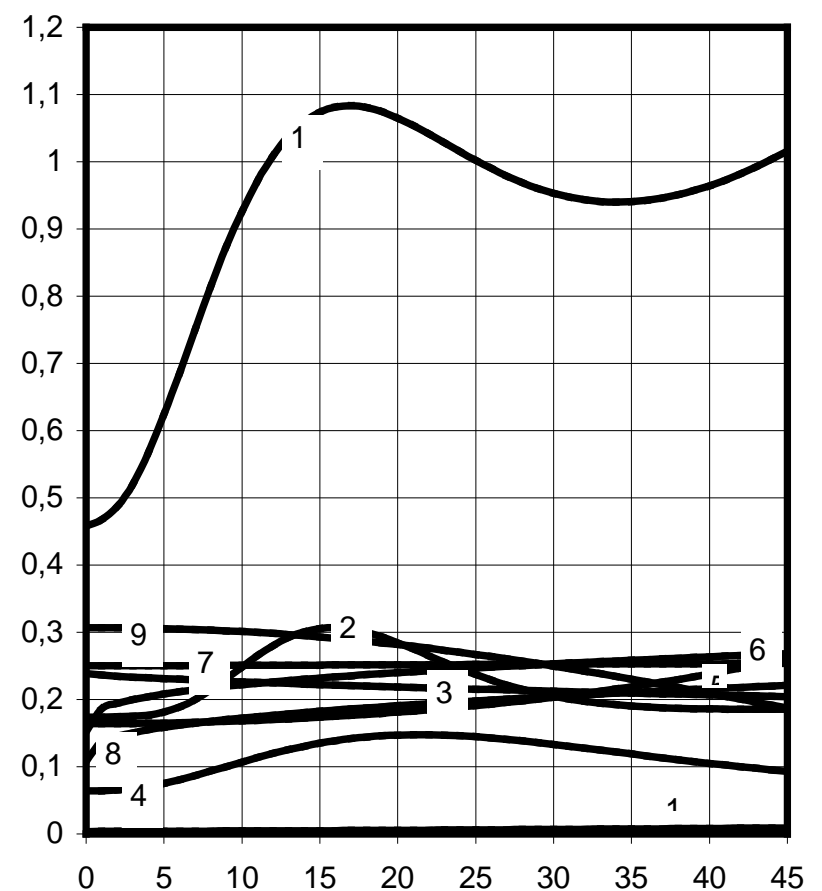

Рис. 2. Сравнение графиков трендов динамики удельной распиловки кругляка на пиломатериалы, $\mathrm{m}^{3} / \mathrm{m}^{3}$ :

1 - Япония; 2 - Италия; 3 - Румыния; 4 - Греция; 5 - Финляндия; 6 - Норвегия; 7 - Франция; 8 - Испания; 9 - СССР; 10 - Тунис

Поэтому нужно перейти на показатель наличного кругляка для изучения динамики лесопользования.

Сравнение стран по темпам динамики наличного кругляка. Применение нового показателя резко меняет картину динамики поведения всех 10 стран.

Наиболее сложная динамика относительного к 1961 г. объема наличного кругляка в Японии. Она осознала путь спада, но потом получила стрессовое возбуждение (вторая составляющая по биотехническому закону). Далее с начала XXI века наблюдается осознанный спад объема наличного в стране кругляка (рис. 3).

В этой связи спад наличного объема кругляка у СССР выглядит как осознанная лесная политика. Но всем понятно, что этот тренд спада был связан не с осознанием долгосрочных путей развития лесного дела, а просто совпал с глобальным социально-экономическим кризисом. Однако это совпадение не случайное, и мы убеждены в том, что российским народам природа дает новый шанс обдумать и осознанно совершить поворот в лесной политике (да и в целом политике природопользования).

Этим шансом правительству и лесному ведомству России в полной мере необходимо воспользоваться. 
A такой глобальный поворот возможен только в том случае, если будет принят и всенародно признан и реализован в течение 30 лет лесоаграрный национальный проект.

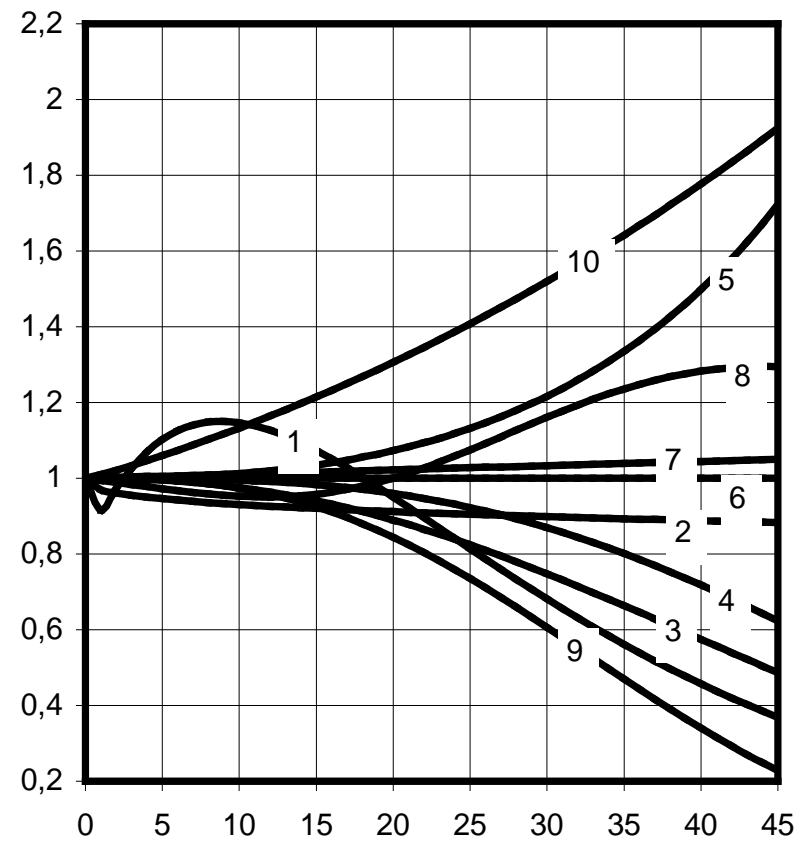

Рис. 3. Сравнение графиков трендов динамики прироста с 1961 г. объемов наличного кругляка (импорт + производство - экспорт): 1 - Япония; 2 - Италия; 3 - Румыния; 4 - Греция; 5 - Финляндия; 6 - Норвегия;

7 - Франция; 8 - Испания; 9 - СССР; 10 - Тунис

Однако без учета сельского хозяйства однобокое развитие лесного хозяйства просто не будет понято населением; часть населения, связанная с лесным хозяйством слишком мала по критической массе и даже чрезвычайно инертнее по сравнению с сельским населением. Поэтому о национальном проекте только по лесному делу говорить не приходится.

Таким образом, России в условиях системного экономического кризиса не следует увеличивать объем наличного кругляка, необходимо одновременно резко сбавить темпы его экспорта, в особенности в приграничные с Россией страны.

Сравнение стран по распиловке наличного кругляка. Фаворит в распиловке наличного кругляка - Япония (рис. 4).

За 44 года Япония увеличила более чем вдвое долю распиловки наличного кругляка.

Конечно же, испытавшие спад в распиловке наличного кругляка Румыния и Италия для России не являются примерами, а остальные семь стран имеют рост объемов выпуска пиломатериалов из наличного кругляка. Динамика этого показателя свидетельствует о кризисе лесопильного производства в нашей стране.

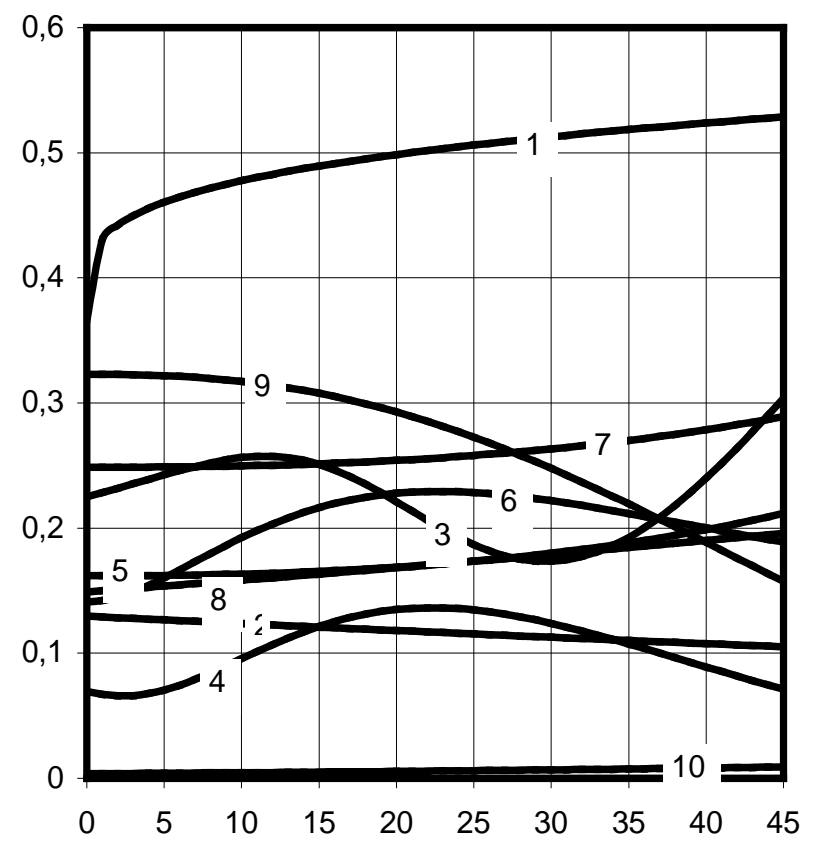

Рис. 4. Сравнение графиков трендов динамики удельной распиловки наличного кругляка (импорт + производство - экспорт), м³/ м³ 1 - Япония; 2 - Италия; 3 - Румыния; 4 - Греция; 5 - Финляндия; 6 - Норвегия;

7 - Франция; 8 - Испания; 9 - СССР; 10 - Тунис

Мы не только находимся на технологическом и техническом уровне XIX века, но еще и «умудрились» за 44 года (с 1961 по 2004 г.г.) более чем вдвое снизить объемы распиловки наличного кругляка. Одним из факторов резкого увеличения объемов экспорта кругляка, конечно же, является беспомощность лесопильной отрасли лесного дела. Значения удельной распиловки наличного кругляка в России и далее будут стремительно снижаться, пока не будет проведена коренная реформа в процессах распиловки за счет приобретения самых лучших в мире японских ленточнопильных станков, обеспечивающих высокое качество обработки поверхности пиломатериалов. Только тогда российские пиломатериалы будут конкурентоспособными на мировом рынке.

Нужно стремиться к 2040 г. достичь по темпам распиловки наличного кругляка уровень Японии. Для этого нужно оставить на современном уровне объем производства кругляка и резко сократить его экспорт.

Затем нужно не менее чем половины наличного кругляка распиливать по самым современным технологиям, причем выпуская доски с лучшим качеством поверхности, чем это ныне делают в Японии, Финляндии, Швеции и Германии. Только такой технологический прыжок способен вывести российское лесопользование на мировой рынок пиломатериалов. 
Иного пути, кроме как осуществления национального долгосрочного проекта «Лесоаграрная Россия», у нас нет.

Средний вариант сценария (вялое развитие) лесного дела не подходит из-за того, что при этом варианте стратегии почти до конца XXI века придется страдать от недостаточной конкурентоспособности отечественных производителей пиломатериалов. Еще раз напомним, что только технологическое «выдавливание» позволит приобретать затем те зарубежные деревообрабатывающие предприятия, которые находятся на границах России с Японией, Китаем, Турцией и Финляндией.

Парадоксально, но факт, что, имея высококачественный кругляк, мы резким увеличением его экспорта еще больше подорвали собственное производство пиломатериалов и в целом российскую экономику. По этому поводу вполне уместно вспомнить пословицу: «Не надо рубить сук, на котором сидишь».

Сравнение стран по удельному производству древесных плит. Из графиков на рисунке 5 видно, что Япония уже в 1980 году осуществила осознанный поворот к снижению производства собственных древесных плит, причисляя эту группу древесной продукции к сырьевым факторам собственной стратегии развития в мире по лесному делу.

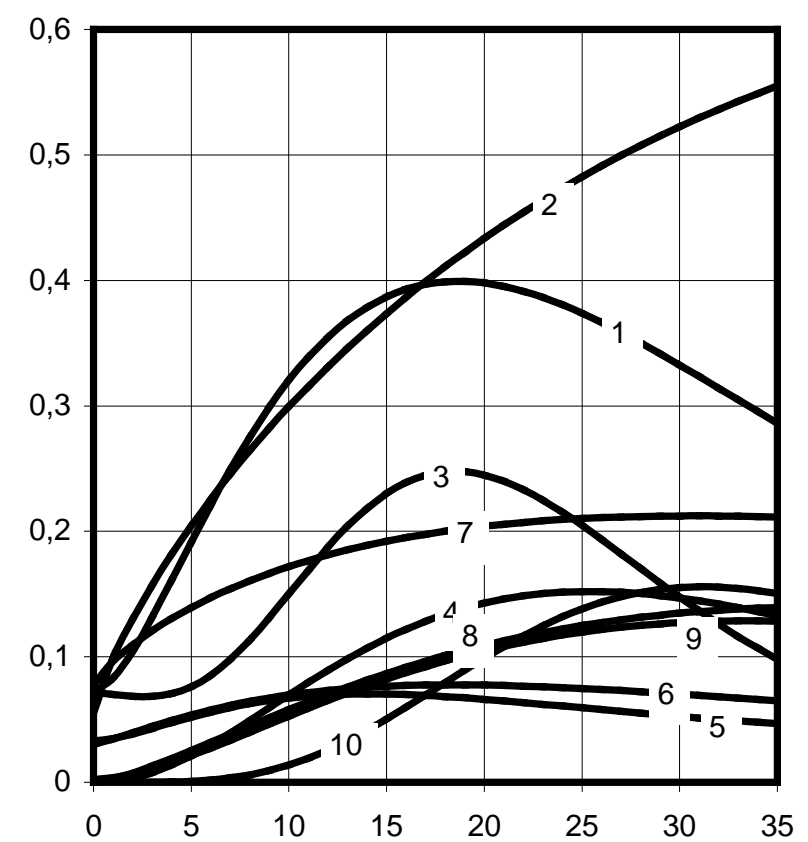

Рис. 5. Сравнение графиков трендов динамики удельного производства древесных плит на гектар леса страны, ${ }^{3} /$ га: 1 - Япония; 2 - Италия; 3 - Румыния; 4 - Греция; 5 - Финляндия; 6 - Норвегия;

7 - Франция; 8 - Испания; 9 - СССР; 10 - Тунис

Однако России еще очень далеко до такого стратегического маневра.

На ближайшие 30 лет (до 2050 года) нашей стране больше подходит Италии, то есть следует составить сверхдальний прогноз и определить оптимистическую стратегию достижения этого прогноза по национальному проекту «Лесоаграрная Россия».

Если осознанно не увеличивать заготовку кругляка (придерживая объемы производства кругляка на уровне примерно 200 млн. м $^{3}$ ) при резком сокращении его экспорта, а также планомерно снижать темпы прироста распиловки наличного кругляка, то для компенсации придется до 10 и более раз наращивать производство древесных плит и в десятки раз (до 120 раз) увеличить производство бумаги и картона. Эта сложная стратегия должна стать основой будущего поведения России в лесном деле с 2020 по 2050 годы.

Еще раз напомним, что многократный рост производства древесных плит, конкурентоспособных на мировом рынке с продукцией, произведенной в Японии, Швеции, Финляндии, Германии и Италии, является истинным спасением российского леса в целом и лесов субъектов Российской Федерации в отдельности.

За будущие 30 лет вполне удастся очистить наши леса от хлама и лесоводственных отходов (такими отходами являются многие лесные массивы, в которых не проводились рубки ухода; они были предоставлены на более чем 100 лет хищнической эксплуатации самим себе).

Сравнение стран по удельному производству бумаги и картона. На рисунке 6 все графики (кроме Румынии) имеют нарастающий характер.

Россия должна ориентироваться на темпы роста объема производства бумаги и картона в Японии, а не в Финляндии или других передовых в лесном деле странах.

Как видно из графиков на рисунке 6, бывший СССР находится почти у оси абсцисс, и даже Тунис многократно его превосходит по темпам роста производства древесной продукции наиболее высокой по значимости группы.

При определении пессимистического варианта прогноза и соответствующей ему сверхдальней стратегии мы рекомендуем вообще не нарушать лесопользованием многие лесные массивы, сохранить их для наших потомков. Поэтому в пессимистическом прогнозе нужно будет принять многие эксплуатируемые ныне лесные массивы за строго охраняемые территории.

В особенности это относится к лесным массивам приграничных субъектов Российской Фе- 
дерации.

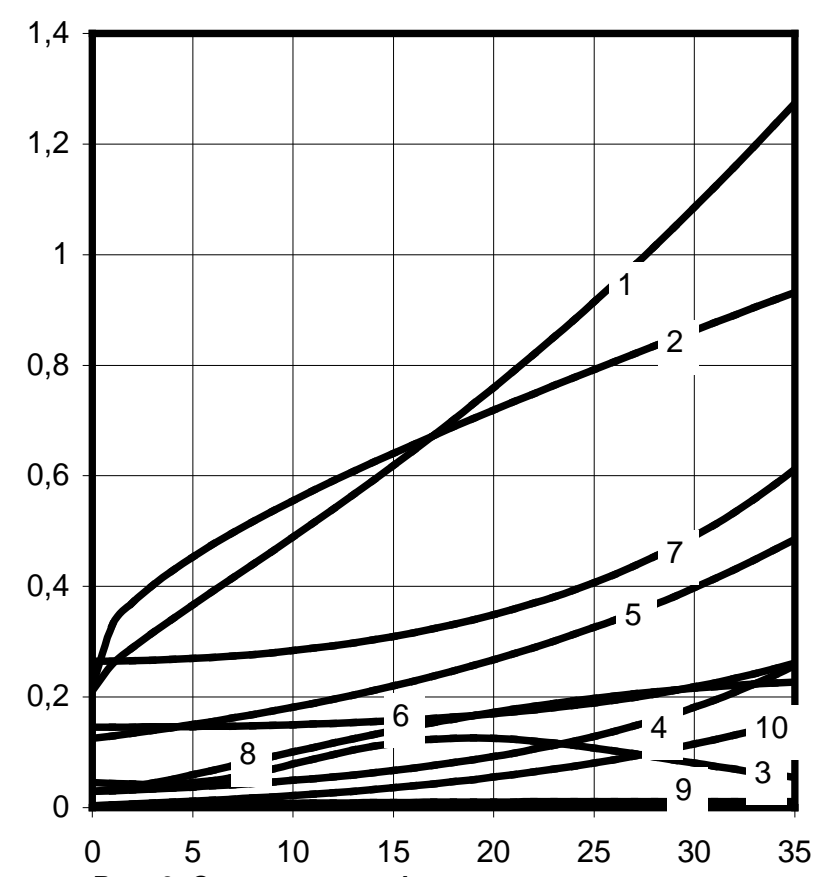

Рис. 6. Сравнение графиков трендов динамики удельного производства бумаги и картона на гектар леса страны, т/га: 1 - Япония; 2 - Италия; 3 - Румыния; 4 - Греция; 5 - Финляндия; 6 - Норвегия;

7 - Франция; 8 - Испания; 9 - СССР; 10 - Тунис

Ранее уже отмечалось, что новая волна реформ в лесном деле начнется в России только с 2024 года. Однако исторической вехой (по прогнозам многих, в том числе и генерала Машкова в конце XIX века) станет для России 2012 год. Если лесное ведомство снова протянет время, то будем надеяться на изменение ситуации через шесть лет.

Заключение. При реализации нормативов лесопользования к 2050 году улучшатся структура и качество лесных массивов России, снизится их расстроенность по распределениям деревьев в каждом древостое. При этом в сотню раз увеличится производство бумаги и картона, в десятки раз производство древесных плит. Объемы производства пиломатериалов не нужно увеличивать по сравнению с современным уровнем, но полностью следует исключить стратегию черновой их обработки путем замены архаичных лесопильных рам на ленточнопильные станки, объем заготовки кругляка нужно будет сдерживать на нынешнем уровне, но с резким снижением криминальной его части.

Отсутствие достоверной статистической информации не позволяет сравнивать Россию с СССР, поэтому пришлось обратиться к данным ФАО ООН за период с 1961 по 2004 годы. Но в них отсутствовали сведения по площади леса с
1995 г. по настоящее время. Только сравнительная динамика за прошедшие 44 года позволила понять нелогичность поведения СССР и в дальнейшем России в лесной политике и технологии лесного дела. Еще в 1994-1996 годах можно было разработать концепцию выращивания новых древостоев и лесопользования в целом в России.

Поэтому за 2014-2020 годы надо успеть разработать и начать внедрение национального долгосрочного проекта «Лесоаграрная Россия» сроком на 30 лет с 2020 по 2050 годы.

Срочно нужно начать реализацию программ лесоводства на уровне лесодефицитных субъектов Российской Федерации с доведением к 2050 году лесистости в них не менее $30 \%$ от общей площади. Нужны также программы сдерживания производства кругляка по России на уровне не более 200 млн. м (с учетом вывода из тени объемов криминальной заготовки кругляка).

Резко следует сократить экспорт кругляка, одновременно реализуя программы увеличения производства и экспорта высококачественных пиломатериалов из наличного в России кругляка в 3-6 раз к 2020 году, увеличения к 2025 году объемов производства высококачественных древесных плит в 10-12 раз, увеличения к 2030 году объемов производства высококачественной бумаги и картона в 80-120 раз, расширения производств древесной продукции из древесной муки, древесных пластиков, а также продукции лесной химии в 300-500 раз.

С 2012 г. отмечается начало технологического прыжка. А если не будет продолжения реформы переработки древесных материалов, то с 2022-2024 гг. всё же начнется коренная реформа лесного, вместе с сельскохозяйственным производством (включая импорт и экспорт), дела. Просто Россия в дальнейшем физически не сможет оставаться сырьевым придатком приграничных государств, почти даром эксплуатирующих российский лес (за последние 30 лет Китай, Финляндия и Турция построили более дюжины ЦБК, а Россия - ни одной).

В недалеком прошлом происходила ложная идентификация лесного дела советскими учеными. Советские лесоводы полностью подчинились заготовителям древесины, а те продолжали вести сплошные рубки древостоев, которые нужно остановить. Нужен будет принципиально новый Лесной кодекс, основанный на доктрине лесного дела на 2020-2050 гг. Необходимо сокращать рубки главного пользования, в особенности сплошные рубки деревьев, их полностью запретить по всей России с 2020 г., тем самым до ос- 
нования преобразовать ГУЛАГовскую систему лесозаготовительных предприятий.

Заново нужно будет возродить лесное и сельскохозяйственное машиностроение.

Самая тяжелая и провальная часть лесного дела России - это распиловка наличного кругляка (наличный объем $=$ импорт + производство кругляка - экспорт). До сих пор даже нет ведомства, отвечающего за производство, экспорт и импорт пиломатериалов.

Лучшими по распиловке наличного кругляка были и остаются Япония, Финляндия, Норвегия, Франция, Испания. В России надо увеличить объемы распиловки наличного кругляка в 3-6 раз при коренном перевооружении отрасли пиломатериалов японскими стационарными ленточнопильными станками, шведскими прицепными ленточнопильными станками, финскими прицепными круглопильными и немецкими углофрезерными устройствами.

В 6-10 раз нужно будет сократить объемы экспорта кругляка, причем весьма безжалостными методами, заменяя экспорт кругляка экспортом качественных пиломатериалов, а больше всего, заменяя кругляк экспортом древесных плит, бумаги и картона.

По удельному производству древесных плит лучшими странами оказались Япония, Италия, Греция, Финляндия и Норвегия. В России объем производства в этой сфере лесного дела нужно увеличить в 10-12 раз.

Без российского лесного машиностроения все потуги через 8-10 лет будут напрасными.

Высокое удельное производство бумаги и картона на гектар национального леса имеют всего четыре страны - Япония, Италия, Финляндия и Франция. Чтобы достичь высокой отдачи от практической реализации лесоаграрного проекта к 2040 году, в России необходимо увеличить производство бумаги и картона в 80-120 раз по сравнению с нынешним уровнем. Одновременно в сельском хозяйстве общая эффективность повысится не менее чем на $30 \%$, причем это увеличение произойдет как компенсация за облесение сельских территорий высокоаграрных субъектов Федерации, но при этом изменится в лучшую сторону и климат, увеличится плодородие почвы.

Таким образом, по всем отраслям лесного дела наилучшие позиции в мире занимают всего две страны - Япония (первое место) и Финляндия (второе место).

Однако для некоторых субъектов Российской Федерации, которые нами были объедине- ны по признаку лесоаграрности в группы и семейства, будет полезным опыт и других стран. Для этого необходимо исследовать статистическую динамику за многие десятилетия лесного дела по каждому субъекту федерации, а также по каждому арендатору участков лесного фонда.

В проект аренды лесного участка нужно вовлекать и сельскохозяйственные угодья. Опыт лесных фермеров Финляндии показывает, что в среднем из 35 га арендуемых земель одна треть должна относиться к землям лесного фонда, одна треть - к землям сельскохозяйственного назначения и еще одна треть - к водно-болотным комплексам. Поэтому только занятые деревьями участки земли настоящему арендатору, в общемто, не нужны, тем более не будет одни только лесные участки арендовать и частный собственник. Закон о частной собственности на лесные и сельскохозяйственные участки, а также на водоохранные зоны и водозащитные полосы должен появиться к 2020 г.

\section{Литература}

1. Мазуркин П.М. Лесоаграрная Россия и мировая динамика лесопользования: научное издание. Йошкар-Ола: МарГТУ, 2007. 334 с.

2. Мазуркин П.М. Лесная аренда и рациональное лесопользование: научное издание. Йошкар-Ола: МарГТУ, 2007. 524 с.

3. Мазуркин П.М. Рациональное природопользование: Лес и лесозаготовка (закономерности лесопользования): учебное пособие. Йошкар-Ола: МарГТУ, 2006. 76 с.

4. Мазуркин П.М., Анисимов С.Е., Михайлова С.И. Рациональное природопользование: учебное пособие. В 3-х ч. Ч. 3: Экологически ответственное лесопользование; под ред. П.М. Мазуркина. Йошкар-Ола: МарГТУ, 2006. 359 с.

5. Мазуркин П.М., Бедертдинов Э.Н. Метод анализа многолетней динамики заготовки кругляка // Успехи современного естествознания. 2008. № 11. С.67-72.

6. Мазуркин П.М., Автономов А.Н. Осознанный поворот в лесном деле Китая // Успехи современного естествознания. 2008. № 11. C.103-107.

7. Мазуркин П.М. «Кодекс кругляка» переделать в кодекс леса // Лесная газета. 2010. № 74(10124). Сентябрь, 28.

8. Мазуркин П.М. Осознанные повороты в лесном деле Японии // Современные наукоемкие технологии. № 7. 2010. С.19-32.

9. Мазуркин П.М. Осознанные модернизации в лесном деле Японии и Финляндии // Международный журнал прикладных и фундамен- 
тальных исследований. № 8. 2010. С.29-41.

10. Мазуркин П.М. Осознанные переходы на выпуск наукоемкой продукции в лесном деле Японии и Финляндии // Международный журнал прикладных и фундаментальных исследований. № 7. 2010. C.52-60.

11. Мазуркин П.М. Качество управления динамикой площади леса в Финляндии // Международный журнал прикладных и фундаментальных исследований. № 8. 2010. С.15-29.

12. Мазуркин П.М. Базовые критерии лесопользования // Современные наукоемкие технологии. № 6. 2010. С.17-32.

13. Мазуркин П.М. Правильно применять слово «лес» // Лесная газета. 2011. № 4 (10154) от 18 янв. и № 5 (10155) от 22 янв.

14. Мазуркин П.М. Коммерческая таксация лесных деревьев. 7 с. Портал WOOD.RU. URL: http://www.wood.ru/ru/loa728.html.

15. Мазуркин П.М. Биотехнический принцип в древесиноведении // Успехи современного естествознания. №1. 2012. С.68-72.

16. Мазуркин П.М. Двойственность лесной политики: Россия за три века // Лесная политика России: федеральный и региональный аспекты; матер. научно-практ. конф. / Под ред. А. С. Алексеева. СПб: СпбЛТУ, 2013. С.26-29.

17. Мазуркин П.М. Противоречия лесной науки и практики России // Матер. II междунар. научно-практ. конф. «Социальная модернизация: проблемы и перспективы». Воронеж: АНО «НАУКА-ЮНИПРЕСС», 2013. С. 52-56.

18. Мазуркин П.М. Парадигма кругляка и кризис лесных технологий // Матер. II междунар. научно-практ. конф. «Социальная модернизация: проблемы и перспективы». Воронеж: АНО «НАУКА-ЮНИПРЕСС», 2013. С. 56-60.

19. Мазуркин П.М. Сортиментностоимостное распределение деревьев // Лесное хозяйство. 2013. № 3. С.36-38.

20. Мазуркин П.М. Россия нужна не лесная, а лесоаграрная политика // Актуальные направления научных исследований XXI века: теория и практика. Сб. научн. тр. по матер. междунар. заочн. научно-практ. конф. ФГБОУ ВПО «ВГЛТА». Воронеж: 2013. № 1(1). С.108-113.

21. Мазуркин П.М. Биокаркас территории: учеб. пос. с грифомУМО РАЕ. Йошкар-Ола: Поволжский ГТУ, 2013. 156 с.

22. Мазуркин П.М. Лесная статистика: нужны ежегодные инвентаризации // Актуальные направления научных исследований XXI века: теория и практика. Сб. научн. тр. по матер. междунар. заочн. научно-практ. конф. ФГБОУ ВПО «ВГЛТА». Воронеж: 2013. № 3(3). С.136-142.

П.М. Мазуркин - д-р техн. наук, проф., акад. РАЕ и РАЕН, член Европейской Академии Естествознания, заслуженный работник высшей школы РФ, засл. деятель науки и техники РМЭ, федеральный эксперт РИНКЦЭ, зав. кафедрой природообустройства ПГТУ 